Article

\title{
Computer-Assisted Design of Environmentally Friendly and Light-Stable Fluorescent Dyes for Textile Applications
}

\author{
Songsong Tang ${ }^{1}\left(\mathbb{D}\right.$, Guoqiang Chen ${ }^{1, *}$ and Gang Sun ${ }^{2, *}$ \\ 1 National Engineering Laboratory for Modern Silk, College of Textile and Clothing Engineering, \\ Soochow University, Suzhou 215123, China; songsongtang@outlook.com \\ 2 Division of Textiles and Clothing, University of California, Davis, CA 95616, USA \\ * Correspondence: chenguojiang@suda.edu.cn (G.C.); gysun@ucdavis.edu (G.S.)
}

Received: 12 October 2019; Accepted: 25 November 2019; Published: 27 November 2019

check for updates

\begin{abstract}
Five potentially environmentally friendly and light-stable hemicyanine dyes were designed based on integrated consideration of photo, environmental, and computational chemistry as well as textile applications. Two of them were synthesized and applied in dyeing polyacrylonitrile (PAN), cotton, and nylon fabrics, and demonstrated the desired properties speculated by the programs. The computer-assisted analytical processes includes estimation of the maximum absorption and emission wavelengths, aquatic environmental toxicity, affinity to fibers, and photo-stability. This procedure could effectively narrow down discovery of new potential dye structures, greatly reduce and prevent complex and expensive preparation processes, and significantly improve the development efficiency of novel environmentally friendly dyes.
\end{abstract}

Keywords: fluorescence; hemicyanine; photo-stability; Gaussian calculations

\section{Introduction}

Fluorescent dyes, an important kind of functional dyes, have been used in many fields such as solar cells [1,2], biological imaging [3,4], probes [5,6], and optical nanoscopy $[7,8]$. However, many fluorescent dyes have been banned and will be phased out in commercial uses due to the concerns of human and environmental health as well as increasing regulations. For example, many azo dyes are prohibited to be used in textiles in European countries since aromatic amines, as potential metabolized products, are harmful to humans and the environment $[9,10]$.

Hemicyanine fluorescent dyes usually have high molar absorption coefficients, broad spectrum width of absorption, and high-quantum yields, because of good coplanarity and conjugated systems with suitable electron donating (EDG) and electron withdrawing groups (EWG) [11-14]. However, these dyes may not have good light stability, especially when applying them in textile materials. Taking compound Z1 (Figure 1a,b) as an example, it possesses perfect chemical structural features and great fluorescence properties (Figure 1c), emitting yellow-red fluorescence [15-18], but the light reflectivity of polyacrylonitrile (PAN) fabric dyed by the compound Z1 decreased greatly when it was exposed to the light for $5 \mathrm{~h}$ (see Figure 1d). Thus, it was hardly used in dyeing fabrics. Fortunately, there are some different ways to improve the photo-stability of the dyes, for example improving the photo-stability of dyes using $\mathrm{TiO}_{2}$ [19], while computational chemistry could estimate behaviors of dyes under light according to quantum chemistry, which could provide theoretical speculations of photo-chemical/light fastness of the dyes [20-25]. 
(a)

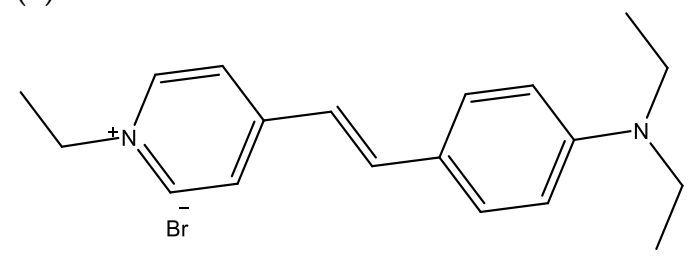

(c)

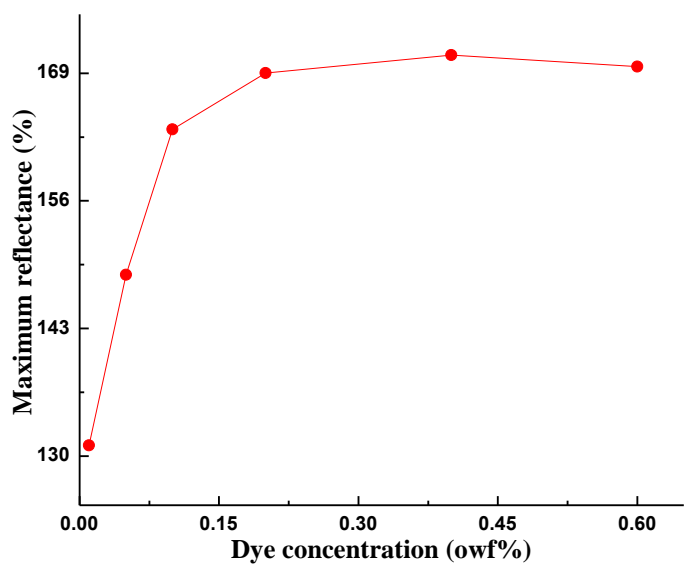

(b)

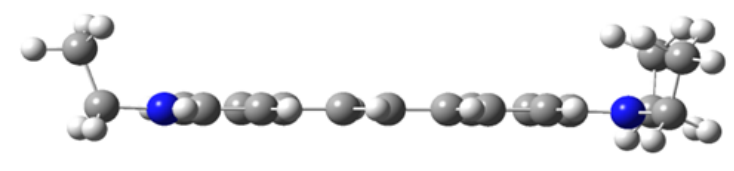

(d)

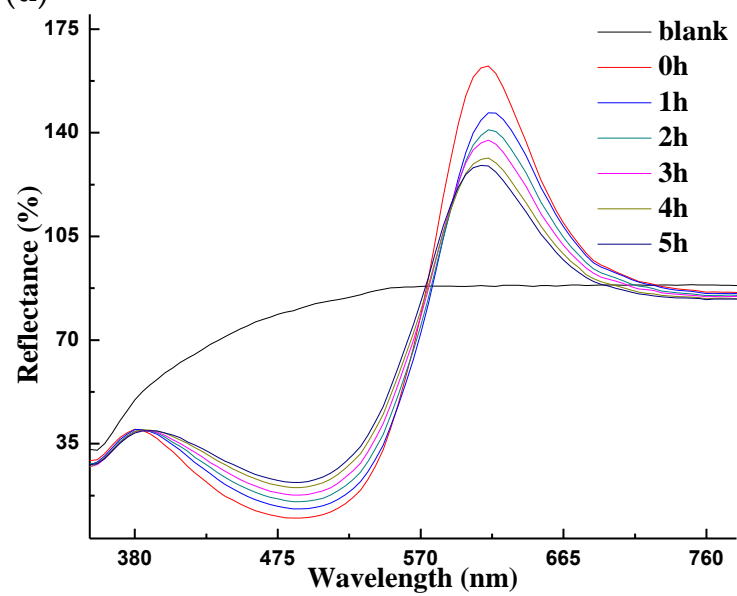

Figure 1. (a,b) Chemical and geometry structure of the hemicyanine-DYE BD; (c) maximum reflectance of dyed polyacrylonitrile (PAN) fabrics (\% owf: $0.01 ; 0.05 ; 0.1 ; 0.2 ; 0.4 ; 0.6)$; (d) reflectivity of PAN fabrics dyed by DYE BD when it was exposed to light for different hours ( $0.4 \%$ owf).

Structural design of fluorescent dyes could be conducted by using computational programs, which could avoid unnecessary work in searching for dyes with improved light-stability. Potential environmental impacts of any designed dye could be estimated by using an ecological structure activity relationships (ECOSAR) predictive model, which is maintained by US Environmental Protection Agency (US-EPA) for predicting aquatic toxicity of chemicals [26,27], while suitability of the designed dyes on different fibers can be estimated by using a Hansen Solubility parameter theory (HSP) [27-30]. In this manuscript, five hemicyanine dyes were designed by using similar starting chemicals and reactions as environmentally friendly fluorescent dyes with improved photo-stability for textile applications. Gaussian 09, a computational program, was employed in analysis of chemical structures of the dyes, while the ECOSAR was adopted to estimate the aquatic-toxicity of raw materials, intermediates, and the dyes. Furthermore, the photo-stability of the dyes were analyzed as well after the affinities of the dyes to fibers were estimated by using Hansen solubility parameters (HSP). In addition, two of the dyes with expected good fluorescent features were prepared, and basic properties of the dyed materials were tested.

\section{Results and Discussion}

\subsection{Biosafety Analysis of Synthetic Processes}

With the results of analysis on the synthesis of the proposed dye molecules, the potential toxicities of the raw materials, all intermediates, and the dyes were estimated by using the ECOSAR. Among all raw materials, compounds $\mathrm{A} 2, \mathrm{~A} 3, \mathrm{~A} 4$, and $\mathrm{A} 5$ showed $\mathrm{LC}_{50}$ and $\mathrm{EC}_{50}$ values higher than 1000, and especially the $\mathrm{LC}_{50}$ (fish, 96h) and $\mathrm{LC}_{50}$ (daphnid, 48h) values of compounds $\mathrm{A} 2, \mathrm{~A} 3$, and $\mathrm{A} 4$ are greater than 10 million. It means that the starting compounds $\mathrm{A} 2, \mathrm{~A} 3, \mathrm{~A} 4$, and $\mathrm{A} 5$ are more environmentally friendly than the compounds A1 and A6.

Compounds A1, A2, and A5 have similar structures but very different toxicity values due to the different substituents. The parent chemical (A1) has $\mathrm{LC}_{50}$ (fish, $96 \mathrm{~h}$ ), $\mathrm{LC}_{50}$ (daphnid, $48 \mathrm{~h}$ ), and $\mathrm{EC}_{50}$ 
(green algae, $96 \mathrm{~h}$ ) values of 292.3, 156.33, and 90.92, respectively. Thus, the A1 is toxic to aquatic lives-especially to the green algae. The corresponding values of the $\mathrm{A} 2$ are about 1000 times greater than those of the $\mathrm{A} 1$, while the values of $\mathrm{LC}_{50}$ and $\mathrm{EC}_{50}$ of the $\mathrm{A} 5$ are about $20-38$ times larger than those of the A1. The results reveal that both sulfonic acid $\left(-\mathrm{SO}_{3} \mathrm{H}\right)$ and carboxyl $(-\mathrm{COOH})$ groups could increase $\mathrm{LC}_{50}$ and $\mathrm{EC}_{50}$ values and decrease the toxicity of the chemicals, while the sulfonic acid group is more effective than carboxyl group to decrease the toxicity of chemicals. The positions of different substituents on the pyridinium ring have different influence on their toxicities. The carboxyl group at the 3 position (compound $\mathrm{A} 5$ ) of the ring increased the values of $\mathrm{LC}_{50}$ and $\mathrm{EC}_{50}$ of the chemicals, but the carboxyl group at the 2 position (compound A6) increases the toxicity of the chemical. Different to the carboxyl group, the sulfonic acid group (see compounds A2, A3, and A4 in Figure S1 and Table 1) decreases the toxicity of the chemicals on any positions.

Table 1. Estimated bio-toxicity of raw materials, intermediates, and designed dyes.

\begin{tabular}{|c|c|c|c|c|}
\hline Item & Name & $\begin{array}{c}\text { Fish } \\
\text { 96h-LC }{ }_{50}(\mathrm{mg} / \mathrm{L})\end{array}$ & $\begin{array}{c}\text { Daphnid } \\
48 \mathrm{~h}-\mathrm{LC}_{50}(\mathrm{mg} / \mathrm{L})\end{array}$ & $\begin{array}{c}\text { Green Algae } \\
\text { 96h-EC }{ }_{50}(\mathrm{mg} / \mathrm{L})\end{array}$ \\
\hline \multirow{6}{*}{ Raw materials } & A1 & 292.3 & 156.33 & 90.92 \\
\hline & A2 & $3,727,904$ & $1,489,483.88$ & $259,458.53$ \\
\hline & A3 & $3,727,904$ & $1,489,483.88$ & $259,458.53$ \\
\hline & A4 & $3,727,904$ & $1,489,483.88$ & $259,458.53$ \\
\hline & A5 & $11,169.25$ & 5724.55 & 2792.02 \\
\hline & A6 & 91.92 & 5.36 & 8.56 \\
\hline \multirow{6}{*}{ Intermediates } & B1 & $15,283,593$ & $5,209,308.5$ & $470,385.34$ \\
\hline & $\mathrm{B} 2$ & $11,033,896,960$ & $3,153,353,728$ & $137,435,888$ \\
\hline & B3 & $11,033,896,960$ & $3,153,353,728$ & $137,435,888$ \\
\hline & B4 & $11,033,896,960$ & $3,153,353,728$ & $137,435,888$ \\
\hline & B5 & $482,951,392$ & $157,749,760$ & $11,945,150$ \\
\hline & B6 & $391,939.94$ & 2527.1 & $61,436.25$ \\
\hline \multirow{6}{*}{ Designed dyes } & Z1 & 3094.48 & 1582.45 & 764.68 \\
\hline & $\mathrm{Z} 2$ & $25,924,188$ & $9,904,030$ & $1,433,391.12$ \\
\hline & $\mathrm{Z3}$ & $25,924,188$ & $9,904,030$ & $1,433,391.12$ \\
\hline & $\mathrm{Z4}$ & $25,924,188$ & $9,904,030$ & $1,433,391.12$ \\
\hline & $\mathrm{Z} 5$ & $90,077.77$ & $44,143.83$ & $17,888.29$ \\
\hline & Z6 & 588.73 & 27.57 & 57.77 \\
\hline
\end{tabular}

All pyridinium salts (compounds B1 to B6) are less toxic than the starting pyridine derivatives based on their higher values of $\mathrm{LC}_{50}$ and $\mathrm{EC}_{50}$. However, the toxicities of the designed dyes, except $\mathrm{Z6}$, are relatively higher than the intermediates; they are significantly lower than the starting compounds and Z1. The increased values of $\mathrm{LC}_{50}$ and $\mathrm{EC}_{50}$ of chemicals are possibly due to the increased water solubility.

\subsection{Fluorescence Properties of Designed Dyes}

Fluorescent properties of these designed dyes were speculated by using the computational program as well. The dye Z1 (see Figures S1 and S2) still possess coplanar conjugated structures even though different substituent groups are not in the same plane. It would emit fluorescence after excited by relevant light.

Table S1 shows the emission and absorption data, calculated by the Gaussian 09 based on the b3lyp/6-31G(d) level of N-methylacridinium chloride in water. The calculated maximum emission wavelength was $482.73 \mathrm{~nm}(2.5648 \mathrm{eV})$, which was close to the data $(498 \mathrm{~nm})$ in reference [31], while the maximum absorption wavelength was $412.93 \mathrm{~nm}$-well matched with the reference data (415 nm) [31]. The maximum absorption and emission wavelengths of designed dyes (shown in Table 2) are varied from that of $Z 1$ but still can emit visible lights after excited by relevant light. 
Table 2. Fluorescence properties calculated by b3lyp/6-31G(d) for designed dyes in water.

\begin{tabular}{|c|c|c|c|c|c|c|c|}
\hline \multirow[b]{2}{*}{ Item } & \multicolumn{3}{|c|}{ Max Absorption Wavelength } & \multicolumn{3}{|c|}{ Max Emission Wavelength } & \multirow{2}{*}{$\begin{array}{l}\text { Stokes } \\
(\mathrm{nm})\end{array}$} \\
\hline & ${ }^{1} \mathrm{E}(\mathrm{ev})$ & $\begin{array}{l}\text { Wavelength } \\
\text { (nm) }\end{array}$ & ${ }^{2} f$ & E (ev) & $\begin{array}{l}\text { Wavelength } \\
\text { (nm) }\end{array}$ & f & \\
\hline $\mathrm{Z1}$ & 2.6105 & 474.94 & 1.4785 & 2.2869 & 542.15 & 1.5166 & 67.21 \\
\hline $\mathrm{Z} 2$ & 2.5576 & 484.77 & 1.4978 & 2.2167 & 559.32 & 1.5085 & 74.55 \\
\hline $\mathrm{Z3}$ & 3.3454 & 370.61 & 0.1305 & - & 419.61 & 1.5554 & 49 \\
\hline $\mathrm{Z} 4$ & 2.6517 & 467.57 & 1.1095 & 2.4054 & 515.45 & 0.9673 & 47.88 \\
\hline $\mathrm{Z} 5$ & 2.4842 & 499.09 & 1.3926 & 2.0643 & 600.60 & 1.2270 & 101.51 \\
\hline Z6 & 2.3827 & 520.35 & 1.2081 & 1.7730 & 699.31 & 0.8955 & 178.96 \\
\hline
\end{tabular}

${ }^{1} \mathrm{E}$ : the energy of the light. ${ }^{2}$ f: oscillator strength.

\subsection{Dyeing Properties Analysis of Designed Dyes}

The affinity between the dyes and fibers could be analyzed by using Hansen solubility parameter theory (HSP), which has been employed in estimating affinity and interactions between molecules [32,33]. HSP distances (Ra values) between the different molecules in Hansen space can be calculated by Equation (1) $[34,35]$. The smaller Ra values represent better affinity between two molecules.

$$
\mathrm{Ra}=\sqrt{4 \Delta \delta_{\mathrm{D}}^{2}+\Delta \delta_{\mathrm{P}}^{2}+\Delta \delta_{\mathrm{H}}^{2}}
$$

$\delta_{\mathrm{D}}$ : The energy from dispersion forces between molecules.

$\delta_{\mathrm{P}}$ : The energy from dipolar forces between molecules.

$\delta_{\mathrm{H}}$ : The energy from hydrogen bonds.

If a dye has high affinity to a fiber, it will be more attractive to the fiber [36], showing better dyeing properties. Five popular natural and chemical fibers were selected to estimate the affinities to the designed dyes. CI Disperse Yellow 11, one of the earliest commercial fluorescent dyes and widely employed in coloration of synthetic fibers (i.e., nylon and PET) and plastics [37,38], was selected randomly to show the practicality of this calculation model.

As shown in Table 3, Ra1 to Ra6 values reflect affinities of a dye to water, cellulose, acrylics (PAN), polyester (PET), Nylon 6, and Nylon 66, respectively. Ra4, Ra5, and Ra6 of CI Disperse Yellow 11 are 8.27, 7.08, and 7.16, which are much lower than Ra1 (36.49) and Ra2 (16.64), indicating that the CI Disperse Yellow has better affinity with PET, Nylon 6, and Nylon 66 than water and cellulose-consistent with the existing data. The designed dye Z1 possess low but close Ra3, Ra4, Ra5, and Ra6 values, which are lower than Ra2 (23.69) and Ra1 (43.02). It means the Z1 could dye PAN, PET, Nylon 6, and Nylon 66 with potential good wash fastness. The Z1 could color cellulose, however due to the small difference of Ra2 and Ra1 values, the wash fastness of the Z1 on cellulose may not be so good. Based on the HSP results, the dye Z2 should have the same dyeing properties to the dyes Z3 and Z4, while the dye Z5 should have same dyeing properties as the dye Z6. Similarly, the dyes Z2, Z3, and $Z 4$ could dye all five fibers but may have different color fastness on the products. 
Table 3. Hansen solubility parameter (HSP) values of the different dyes and Hansen distances to water (Ra1), cellobiose (Ra2), polyacrylonitrile (Ra3), poly (ethylene terephthalate) (Ra4), Nylon 6 (Ra5), and Nylon 66 (Ra6).

\begin{tabular}{|c|c|c|c|c|c|c|c|c|c|}
\hline \multirow{2}{*}{ Dye } & \multicolumn{3}{|c|}{ HSP (MPa1/2) } & \multirow{2}{*}{$\begin{array}{c}\text { Ra1 } \\
\text { (MPa1/2) }\end{array}$} & \multirow{2}{*}{$\begin{array}{c}\mathrm{Ra2} \\
(\mathrm{MPa} 1 / 2)\end{array}$} & \multirow{2}{*}{$\begin{array}{c}\mathrm{Ra3} \\
\text { (MPa1/2) }\end{array}$} & \multirow{2}{*}{$\begin{array}{c}\text { Ra4 } \\
(\text { MPa1/2) }\end{array}$} & \multirow{2}{*}{$\begin{array}{c}\text { Ra5 } \\
\text { (MPa1/2) }\end{array}$} & \multirow{2}{*}{$\begin{array}{c}\text { Ra6 } \\
\text { (MPa1/2) }\end{array}$} \\
\hline & $\delta_{D}$ & $\delta_{P}$ & $\delta_{H}$ & & & & & & \\
\hline Z1 & 18.4 & 3.0 & 1.7 & 43.02 & 23.69 & 14.48 & 9.22 & 9.90 & 9.99 \\
\hline $\mathrm{Z} 2$ & 18.9 & 8.4 & 10.4 & 33.49 & 13.64 & 9.47 & 7.69 & 4.47 & 4.53 \\
\hline $\mathrm{Z3}$ & 18.9 & 8.4 & 10.4 & 33.49 & 13.64 & 9.47 & 7.69 & 4.47 & 4.53 \\
\hline $\mathrm{Z} 4$ & 18.9 & 8.4 & 10.4 & 33.49 & 13.64 & 9.47 & 7.69 & 4.47 & 4.53 \\
\hline Z5 & 18.5 & 4.3 & 4.6 & 39.93 & 20.51 & 12.57 & 7.78 & 7.43 & 7.53 \\
\hline $\mathrm{Z} 6$ & 18.5 & 4.3 & 4.6 & 39.93 & 20.51 & 12.57 & 7.78 & 7.43 & 7.53 \\
\hline CI Disperse Yellow 11 & 20.2 & 5.3 & 8.7 & 36.49 & 16.64 & 12.53 & 8.27 & 7.08 & 7.16 \\
\hline $\mathrm{H}_{2} \mathrm{O}$ & 15.5 & 16 & 42.3 & 0 & 20.26 & 36.09 & 39.78 & 36.51 & 36 \\
\hline Cellulose (cellobiose) & 18.7 & 12.5 & 23.4 & 20.26 & - & - & - & - & - \\
\hline PAN & 17.9 & 16.7 & 6.3 & 36.09 & - & - & - & - & - \\
\hline PET & 19.6 & 11.7 & 3.6 & 39.78 & - & - & - & - & - \\
\hline Nylon 6 & 18.5 & 11.3 & 7.1 & 36.51 & - & - & - & - & - \\
\hline Nylon 66 & 18.5 & 11.4 & 7.1 & 36 & - & - & - & - & - \\
\hline
\end{tabular}

Comparing the dyes Z1-Z6, they have similar conjugated structures but different dyeing properties due to varied substitutes. Both of the carboxyl and sulfonic acid groups can improve the affinity between dyes and certain polymers, but the sulfonic acid group showed stronger effect than that of the carboxyl group. It should be pointed that the disperse dyes, such like CI Disperse Yellow 11, were hardly used to color PAN fiber, while some water-soluble dyes are difficult to dye PET fiber in practice. Thus, we should analyze the dyeing properties not only based on the HSP distance, but also need to consider the practical/commercial knowledge of dyeing fibers.

\subsection{Photo-Stability Analysis of Designed Dyes}

Photo-stability, an important parameter of dyes, is the main concern when selecting dyes for textile application. According to the literature [20,24], photo-degradation of hemicyanine dyes could be caused by reactions between the dyes and reactive oxygen species-such as singlet oxygen $\left({ }^{1} \mathrm{O}_{2}\right)$ and superoxide anion $\left(\mathrm{O}_{2}{ }^{-}\right)$existing in the air. Thus, the reactions between the designed dyes and two kinds of reactive oxygen were analyzed by the computational and quantum chemistry method to estimate the photo-stability of the designed dyes.

As shown in Figure 2, the highest occupied molecular orbitals (HOMO) and lowest unoccupied molecular orbitals (LUMO) of the designed dyes were calculated by the Gaussian 09. The atoms were numbered in Figure S6. Comparing the HOMOs and LUMOs of the dyes, the different substituents and their positions on the pyridinium ring have varied influence, especially for the dyes of $Z 1$ and $Z 4$. As shown in Table 4 and Table S2, the HOMO and LUMO orbitals of ${ }^{1} \mathrm{O}_{2}, \mathrm{O}_{2}{ }^{-},{ }^{3} \mathrm{O}_{2}$, and $\mathrm{Z1}-\mathrm{Z6}$ were calculated based on hf/6-31 $+\mathrm{g}(\mathrm{d})$. 

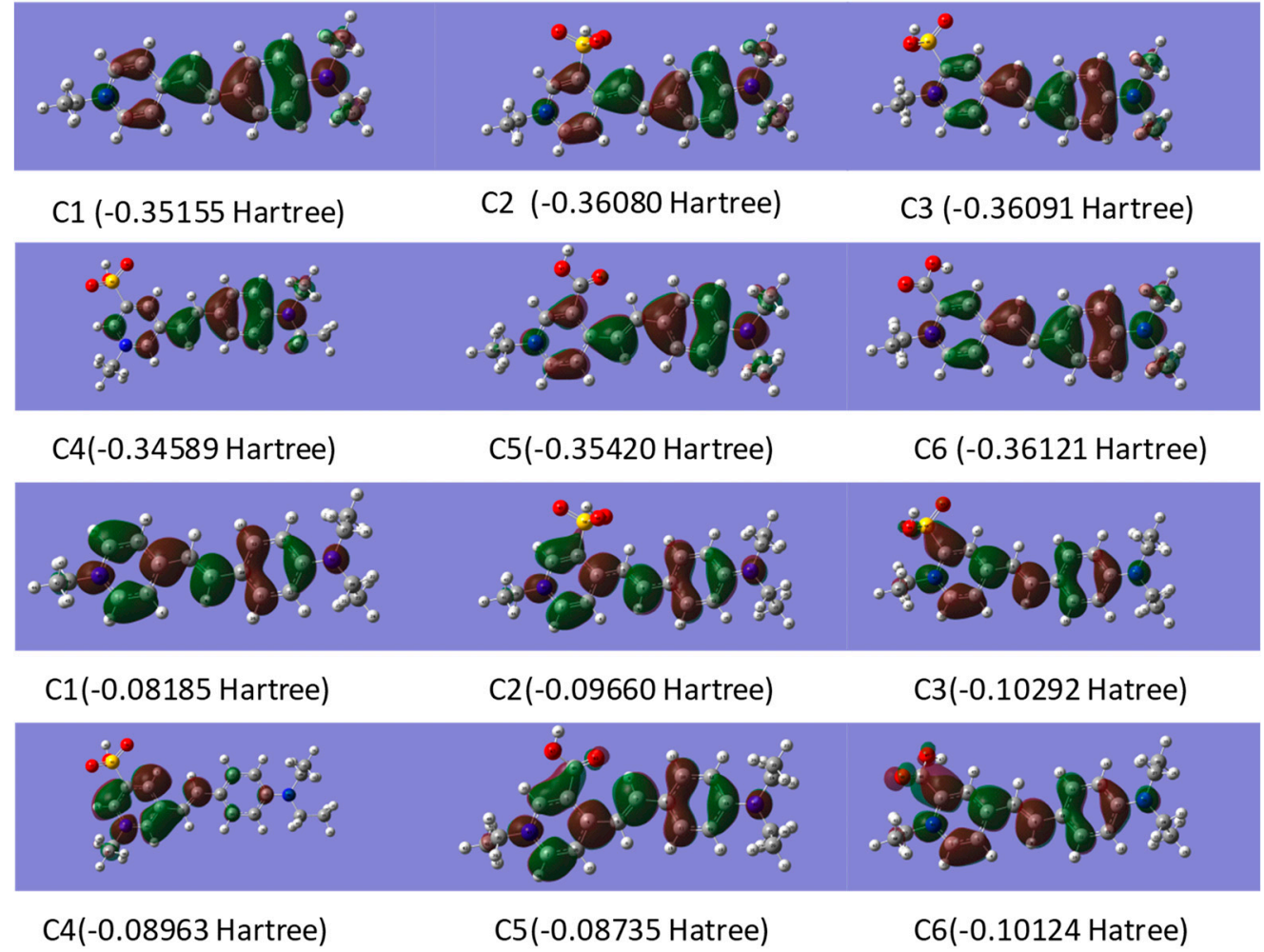

Figure 2. Highest occupied molecular orbitals (HOMO) (first six) and lowest unoccupied molecular orbitals (LUMO) (last six) orbitals of Z1-Z6.

Table 4. HOMO and LUMO orbital levels of ${ }^{3} \mathrm{O}_{2}, \mathrm{O}_{2}{ }^{-}$, and ${ }^{1} \mathrm{O}_{2}$ based on hf/6-31 $+\mathrm{g}(\mathrm{d})$.

\begin{tabular}{|c|c|c|c|c|c|c|c|c|}
\hline \multirow{2}{*}{\multicolumn{3}{|c|}{$\begin{array}{c}\text { Eigenvalues } \\
\text { (Hartree) }\end{array}$}} & \multicolumn{2}{|c|}{${ }^{3} \mathrm{O}_{2}$} & \multicolumn{2}{|c|}{${ }^{1} \mathrm{O}_{2}$} & \multicolumn{2}{|c|}{$\mathrm{O}_{2}^{-}$} \\
\hline & & & HOMO & LUMO & HOMO & LUMO & HOMO & LUMO \\
\hline \multirow{8}{*}{$\begin{array}{l}\text { Atomic orbital } \\
\text { coefficients }\end{array}$} & \multirow{4}{*}{ O1 } & $2 \mathrm{~S}$ & 0 & 0.12445 & 0 & 0 & 0 & 0.11664 \\
\hline & & $2 \mathrm{PX}$ & 0 & 0 & 0 & 0.4592 & 0.49969 & 0 \\
\hline & & $2 \mathrm{PY}$ & 0.54995 & 0 & 0.53402 & 0 & 0 & 0 \\
\hline & & $2 \mathrm{PZ}$ & 0 & -0.06966 & 0 & 0 & 0 & -0.07467 \\
\hline & \multirow{4}{*}{$\mathrm{O} 2$} & $2 S$ & 0 & -0.12445 & 0 & 0 & 0 & -0.11664 \\
\hline & & $2 \mathrm{PX}$ & 0 & 0 & 0 & -0.4592 & -0.49969 & 0 \\
\hline & & $2 \mathrm{PY}$ & -0.54995 & 0 & -0.53402 & 0 & 0 & 0 \\
\hline & & $2 \mathrm{PZ}$ & 0 & -0.06966 & 0 & 0 & 0 & -0.07467 \\
\hline
\end{tabular}

According to the basic principles of linear combination of atomic orbitals (LCAO)-molecular orbital theory (MO), HOMO of the dyes and LUMO of the reactive oxygen species should have similar symmetry, energy levels, as well as the maximum overlap in the orbitals. Obviously, the HOMO orbitals energy of the dyes is close to that of the LUMO orbital of ${ }^{1} \mathrm{O}_{2}$, while the energy of HOMO orbital of $\mathrm{O}_{2}{ }^{-}$is approximate to that of the LUMO orbitals of the dyes. Thus, the ${ }^{1} \mathrm{O}_{2}$ LUMO orbitals could react with the HOMO orbitals of the dyes, while the $\mathrm{O}_{2}{ }^{-} \mathrm{HOMO}$ orbitals could react with the LUMO orbitals of the dyes-causing photo-oxidation. The $\mathrm{O}_{2}{ }^{-1}$ could be more powerful than ${ }^{1} \mathrm{O}_{2}$ in photo-oxidation process since the energy gap between the LUMO orbitals of the dyes and $\mathrm{O}_{2}{ }^{-} \mathrm{HOMO}$ orbitals are lower than energy gap between the HOMO orbital of the dyes and ${ }^{1} \mathrm{O}_{2}$ LUMO orbital (see Table S3). The active positions of HOMO and LUMO orbitals of the dyes are summarized from Figure 2 and Table S2, and listed in Table 5. 
Table 5. HOMO/LUMO orbitals of active positions of dyes.

\begin{tabular}{|c|c|c|c|c|}
\hline \multirow{2}{*}{ Item } & \multicolumn{2}{|c|}{ HOMO 8} & \multicolumn{2}{|c|}{ LUMO } \\
\hline & Active Position & $\begin{array}{c}\text { Atomic Orbital } \\
\text { Coefficients }\end{array}$ & Active Position & $\begin{array}{c}\text { Atomic Orbital } \\
\text { Coefficients }\end{array}$ \\
\hline \multirow{3}{*}{$\mathrm{Z1}$} & \multirow{3}{*}{ N34-C17 } & \multirow{3}{*}{$0.27263,-0.13943$} & N46-C2 & $0.22269,-0.18852$ \\
\hline & & & N46-C3 & $0.22269,-0.15797$ \\
\hline & & & N34-C17 & $0.10212,-0.13939$ \\
\hline \multirow{3}{*}{$\mathrm{Z} 2$} & \multirow{3}{*}{ N34-C17 } & \multirow{3}{*}{$0.26495,-0.1272$} & N45-C2 & $0.19891,-0.14321$ \\
\hline & & & N45-C3 & $0.19891,-0.17116$ \\
\hline & & & N34-C17 & $0.11526,-0.14978$ \\
\hline \multirow{3}{*}{$\mathrm{Z3}$} & \multirow{3}{*}{ N34-C17 } & \multirow{3}{*}{$0.26631,-0.13001$} & N44-C2 & $0.22645,-0.20734$ \\
\hline & & & N44-C3 & $0.22645,-0.15098$ \\
\hline & & & N34-C17 & $0.10354,-0.13363$ \\
\hline \multirow{3}{*}{$\mathrm{Z} 4$} & \multirow{3}{*}{ N39-C18 } & \multirow{3}{*}{$0.28064,-0.14857$} & N43-C41 & $0.28690,-0.16810$ \\
\hline & & & N43-C4 & $0.28690,-0.25597$ \\
\hline & & & $\mathrm{C} 2-\mathrm{C} 1$ & $0.30619,-0.15157$ \\
\hline \multirow{3}{*}{$\mathrm{Z} 5$} & \multirow{3}{*}{ N33-C16 } & \multirow{3}{*}{$0.26451,-0.13186$} & N45-C2 & $0.18462,-0.20217$ \\
\hline & & & N45-C3 & $0.18462,-0.09251$ \\
\hline & & & N33-C16 & $0.10986,-0.14634$ \\
\hline \multirow{3}{*}{$\mathrm{Z} 6$} & \multirow{3}{*}{ N34-C17 } & \multirow{3}{*}{$0.26918,-0.1317$} & N44-C2 & $0.22579,-0.20415$ \\
\hline & & & N44-C3 & $0.22579,-0.14513$ \\
\hline & & & N34-C17 & $0.10063,-0.13091$ \\
\hline
\end{tabular}

The dyes Z1-Z6 have similar active positions in HOMO and LUMO orbitals due to the similar chemical structures. The atomic orbital coefficient of the dye $Z 4$ in HOMO orbital was higher than that of the Z1, while the energies of HOMO orbitals of the dyes Z2, Z3, Z5, and Z6 are close to each other and lower than that of $Z 1$, indicating that the dye $Z 4$ would be more active than other dyes. Also, the dyes $\mathrm{Z2}, \mathrm{Z3}, \mathrm{Z5}$, and $\mathrm{Z} 6$ would be more stable than the dye $\mathrm{Z1}$ during the photo-oxidation process in terms of the lower atomic orbital coefficients in HOMO orbitals. The LUMO orbitals of the dyes are more complicated since they have three active positions in LUMO orbitals. Three atomic orbital coefficients (green values) of the dyes Z2, Z5, and Z6 were lower than that of the dye Z1, while the other atomic orbital coefficients of the dyes are increased (red values) or decreased compared to the dye Z1. However, the atomic orbital coefficients of N45-C3 in the dye Z5 are lower than that of N46-C3 in dye Z1, and the atomic orbital coefficients of the N33-C16 in dye Z5 are higher than that of N34-C17 in dye Z1. The same situation could be found in dye Z2, meaning that dyes Z2, Z5, and Z1 have similar reactive LUMO orbitals. Based on the above analysis and Table S4, dyes Z2 and Z5 would have better photo-stability than the dyes Z3, Z4, and Z6, but it is hard to determine whether dyes Z2 and Z5 have better photo-stability than dye Z1.

\subsection{Synthesis and Applications of Dyes Z2 and Z5}

Following the theoretical speculations on ideal fluorescent dyes for textile applications, dyes Z2 and Z5 were selected to prove the practicality of the theory. The prepared dyes Z2 and Z5 were confirmed by FTIR, UV-vis, and fluorescent spectra (Figure 3). As shown in Figure 3a, the FTIR spectrum of dye $Z 2$ is similar to that of dye $Z 5$ due to the similar chemical structures. The differences in the FTIR of dyes Z2 and Z5 are marked in different colors in Figure 3a. Obviously, there are characteristic absorption peaks $\left(1743 \mathrm{~cm}^{-1}, 1243 \mathrm{~cm}^{-1}\right)$ of carboxyl group in $Z 5$, while the $632 \mathrm{~cm}^{-1}$ is the absorption peak of $\mathrm{S}=\mathrm{O}$ in sulfonic group of $\mathrm{Z} 2$. The absorption peaks of carbon double bonds (-C $=C-$ ) of dye $Z 2$ and $Z 5$ are about $1630 \mathrm{~cm}^{-1}$ and $1650 \mathrm{~cm}^{-1}$, respectively, while the absorption peaks of pyridine (Py) of dyes Z2 $\left(1574 \mathrm{~cm}^{-1}\right)$ and $Z 5\left(1577 \mathrm{~cm}^{-1}\right)$ are slightly different. 
(a)

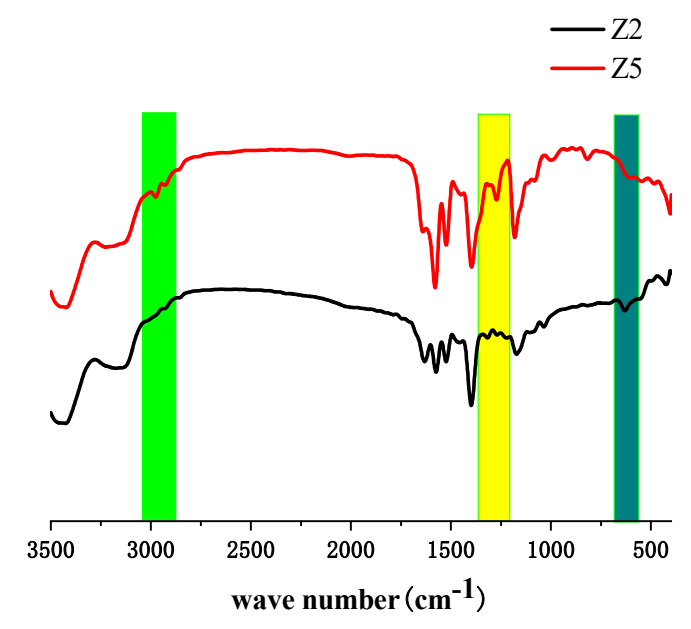

(c)

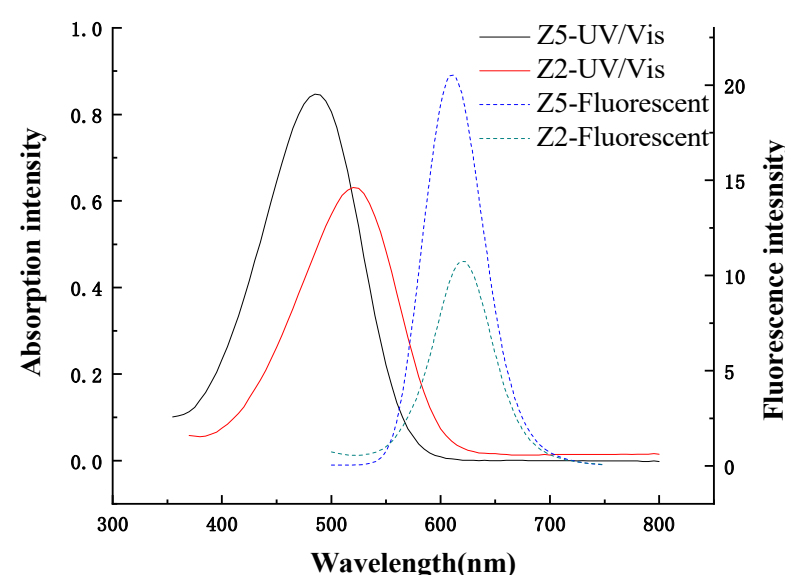

(b)

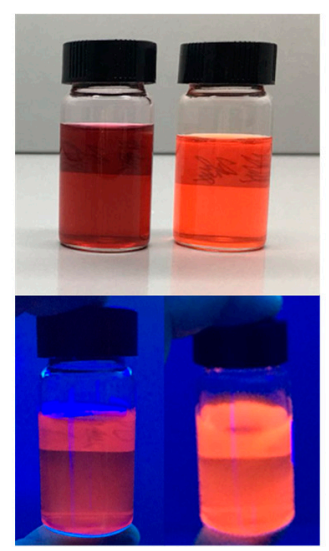

(d)

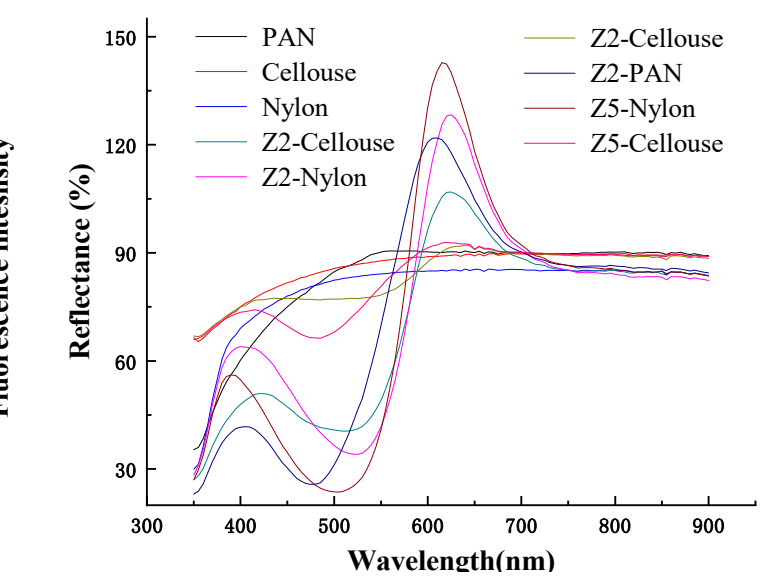

Figure 3. (a) FTIR spectral of dyes Z2 and Z5; (b) ethanol solutions of dyes Z2 (left) and Z5 (right) under D65 (upper) and UV (bottom) light; (c) absorption and emission spectra of dyes Z2 and Z5 in water; (d) reflectivity of different fabrics dyed by dyes Z2 and Z5.

Ethanol solutions of Z2 and Z5 under UV and D65 light display different colors (Figure 3b). According to Figure $3 c$, the experimental maximum absorbance wavelengths of dyes $Z 2$ and $Z 5$ were around $520 \mathrm{~nm}$ and $490 \mathrm{~nm}$, and the measured maximum emission wavelengths of them were about $622 \mathrm{~nm}$ and $612 \mathrm{~nm}$, respectively. The results indicated that the measured maximum absorption and emission wavelengths are close to these estimated data, especially for the dye Z5 (see Tables S5-S7). The synthesized dyes (Z2 and Z5, Figures S7 and S9) and commercial Rhodamine B (Figure S8) were used to dye PAN, cellulose, and nylon (2 g/piece, woven, Shanghai Textile Industry Institute of Technical Supervision, Figure 3d and Figure S7a) following Figures S10 and S11 in an X-5 DYEING machine (Foshan HUANGJU, China) with liquor ratio 50:1 at pH 4.5-5.0 by an acetic acid-sodium acetate buffer solution. The dye solutions were prepared with dyes ( $1 \% \mathrm{owf})$, sodium sulphate $(3 \mathrm{~g} / \mathrm{L})$, and surfactant $(0.5 \mathrm{~g} / \mathrm{L})$. The temperature was raised from room temperature to $100{ }^{\circ} \mathrm{C}$ at the rate of $1{ }^{\circ} \mathrm{C} / \mathrm{min}$ after the fabrics were immersed into the dye solutions. After that, dyeing took place at this temperature and continued for a further $60 \mathrm{~min}$; the dye solutions were then cooled to $70{ }^{\circ} \mathrm{C}$ at $1.25^{\circ} \mathrm{C} / \mathrm{min}$, and the dyed fabrics were washed thoroughly in distilled water and dried in the open air $[39,40]$. The three blank fabrics have no obvious absorption and emission peaks under visible light, while the six dyed fabrics displayed obvious absorption and emission peaks under the visible light, 
indicating that dyes Z2 and Z5 can color PAN, nylon, and cotton fabrics. However, different to the dyed PAN and Nylon, the cotton fabrics dyed by Z2 and Z5 displayed small adsorption and emission intensity. Similar to the water solutions of dyes, the maximum absorption wavelengths of dye $\mathrm{Z} 2$ on PAN and Nylon were around $510 \mathrm{~nm}$, and the maximum emission wavelengths of them were around $625 \mathrm{~nm}$. The maximum absorption wavelengths of dye Z5 on PAN and Nylon were about $475 \mathrm{~nm}$ and $505 \mathrm{~nm}$, while the maximum emission wavelengths of dye Z5 on PAN and nylon were around $610 \mathrm{~nm}$ and $615 \mathrm{~nm}$, respectively.

As shown in Figure 2, the energy of HOMO orbitals of $\mathrm{Z2}$ and $\mathrm{Z} 5$ were -0.36080 hartree and -0.35420 hartree, so the energy gap between the HOMO orbital of dye $\mathrm{Z} 2$ and ${ }^{1} \mathrm{O}_{2}$ LUMO (0.01129 hartree) orbital was greater than the energy gap between the HOMO orbital of dye Z5 orbitals and ${ }^{1} \mathrm{O}_{2}$ LUMO orbital, which means that dye $\mathrm{Z} 5$ was more reactive than dye $\mathrm{Z} 2$ in terms of HOMO orbitals; similarly but different to the HOMO orbital, the energy gap between the LUMO $\left(-0.10124\right.$ hartree) orbital of dye $\mathrm{Z} 5$ and $\mathrm{O}_{2}{ }^{-} \mathrm{HOMO}(-0.12516$ hartree) orbital was smaller than the energy gap between the LUMO (-0.09660 hartree) orbitals of dye $\mathrm{Z} 2$ and $\mathrm{O}_{2}{ }^{-} \mathrm{HOMO}$ orbital. Thus, dye $\mathrm{Z} 2$ would be more stable than dye $\mathrm{Z} 5$ when it reacts with reactive oxygen species. However, when compared with Z1, the energy of the HOMO and LUMO orbitals of dye Z2 and Z5 were lower than that of dye $Z 1$, so it is hard to determine whether dyes $Z 2$ and $Z 5$ have better photo-stability than dye Z1. According to Figure 4, the maximum reflectivity of the Z1 dyed fabric lost about $20 \%$ of initial color intensity after $5 \mathrm{~h}$ light exposure. The $\mathrm{Z} 2$ dyed fabric only displayed about $16 \%$ loss in color intensity after the same duration of light exposure, while the Z5 dyed fabric showed about $24 \%$ loss in color intensity, meaning that dye Z2 had better photo-stability than dye Z1, but dye Z5 showed slightly lower photo-stability than dye Z1 in dyed PAN fabrics. The results are a little disappointing but will be addressed in future work.

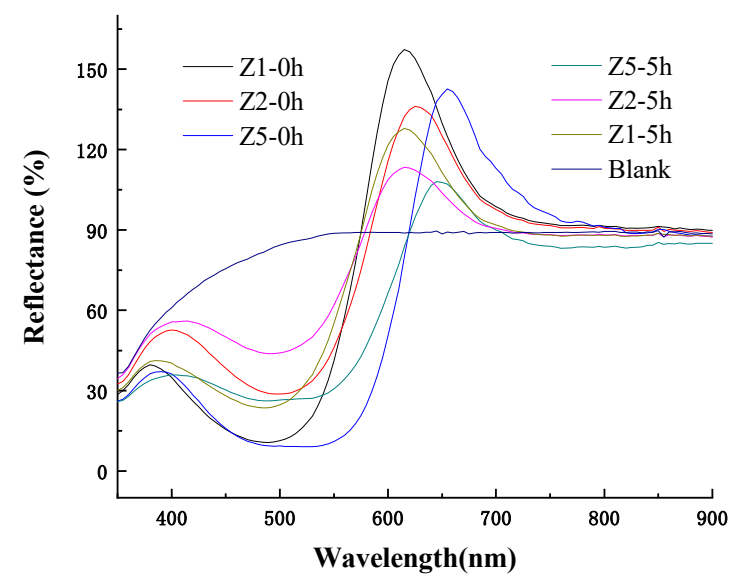

Figure 4. Light stability of the Z2 and Z5 dyed PAN fabrics exposed to the light for 0 and $5 \mathrm{~h}$.

\section{Materials and Methods}

\subsection{Software and Calculation Methods}

Geometry structures of the designed dye were optimized by using Gaussian 09 based on the b3lyp method with 6-31G(d) basis sets [41-43], and their charge distributions, enthalpies, and Gibbs free energies were estimated at b3lyp/6-31G(d) level [41,44-46], while the maximum absorption and emission wavelengths of them were predicted by using time-dependent density functional theory (TD-DFT) at the b3lyp/6-31G(d) level [47-52]. ECOSAR was used to predict aquatic toxicity of the chemicals by using the database based on the quantitative structure-activity relationship (QSAR) [53,54]. The Hansen distances of the dyes to water and fiber materials were calculated based on HSPiP 4.1.07 and used to estimate the different affinities between dyes, water, and fiber materials. 


\subsection{Design and Feasibility Analysis of Dyes}

\subsubsection{Route Design of Hemicyanine Dyes}

As shown in Figure 5, the hemciayanine dyes could be prepared by 2 steps; the chemical structures of raw materials, intermediates, and dyes are shown in Figure S1, while the geometry structures of the designed dyes are shown in Figure S2. Z1 (DYE-BD) could be easily synthesized in two steps following the references [15-18], and the route of the synthesis can serve as an example to illustrate the designed routes. The nitrogen center of pyridine features a basic lone pair of electrons; consequently, pyridine is a strong nucleophile. Thus, pyridine could react with 1-bromoethane to form pyridinium, while the second reaction is a typical Knoevenagel condensation reaction between the methyl group on the pyridinium and the carbonyl group in 4-diethylaminobenzaldehyde.

(a)
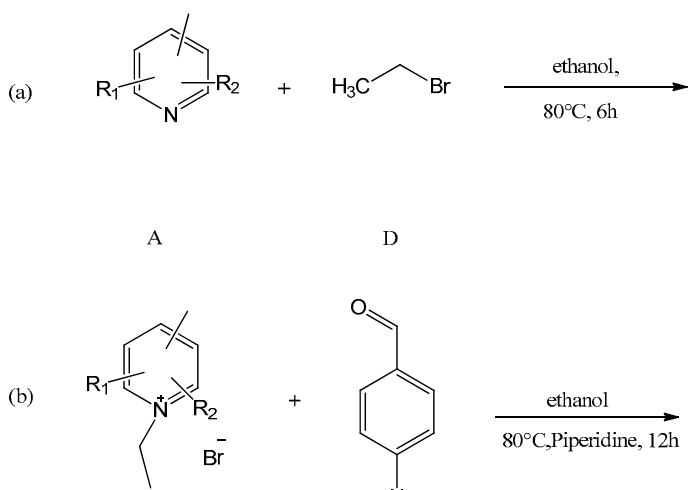

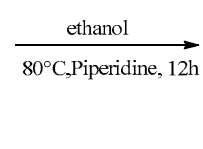

D

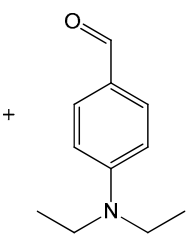

E

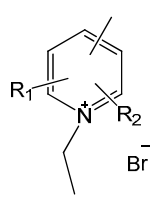

B

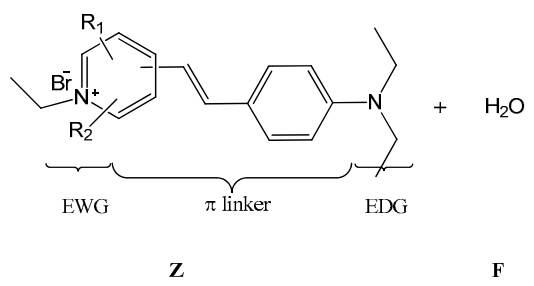

B4: 1-ethyl-3-methyl-5-sulfopyridin-1-ium bromide

B5: 3-carboxy-1-ethyl-4-methylpyridin-1-ium bromide

B6: 2-carboxy-1-ethyl-4-methylpyridin-1-ium bromide

Z1: (E)-4-(4-(diethylamino)styryl)-1-ethylpyridin-1-ium bromide

Z2: (E)-4-(4-(diethylamino)styryl)-1-ethyl-3-sulfopyridin-1-ium bromide

Z2: (E)-4-(4-(diethylamino)styryl)-1-ethyl-3-sulfopyridin-1-ium bromide

Z3: (E)-4-(4-(diethylamino)styryl)-1-ethyl-2-sulfopyridin-1-ium bromide

75: (E)-3-carboxy-4-(4-(diethylamino)styryl)-1-ethylpyridin-1-ium bromide

Z6: (E)-2-carboxy-4-(4-(diethylamino)styryl)-1-ethylpyridin-1-ium bromide

Figure 5. General method for prepare designed dyes. (a) formation of pyridinium; (b) preparation of designed dye.

Although the Z1 in Figure 5 has been reported and investigated by researchers [15-18], the properties of other chemicals could be changed by different substituent groups, and the reactivity of intermediates would be changed as well. Thus, analysis and design of proper synthesis routes are important and necessary. The feasibilities of the routes were analyzed by using the computational methods.

\subsubsection{Analysis of Charge Density of Intermediates}

The first step of the preparation route of designed dyes in Figure 5 is a formation of quaternary pyridinium salts on pyridine derivatives. Due to the existence of unconjugated lone pair electrons on $\mathrm{N}$ in pyridine rings, all six derivatives of pyridine can form the corresponding pyridinium salts easily (see Figures S3-S5). The second step reaction, a nucleophilic reaction, is between the pyridinium salts and 4-diethylaminobenzaldehyde, while the reactive sites on the pyridinium salts are carbons bearing more electrons and more negative charges.

Figure 6 displays the charge distributions of the pyridinium intermediates. As a result of calculation, for the pyridinium salt (g) in Figure 6, the carbon, with an electron density of -0.391 , in the methyl group should be the reactive site when it reacts with 4-diethylaminobenzaldehyde, while the 
methyl group in compound B1 is more reactive than methyl group in compound A1, which can be confirmed in the references [55-61]. Thus, the more negative charges of carbon in methyl group, the more reactive the methyl group will be. Sulfonic acid and carboxyl groups have a complex influence on the charge of the atoms in pyridinium salts. The carboxyl group ( 2 position) increases the electronegativity of the carbon in methyl group slightly, but the carboxyl ( 3 position) decreases the charge on the carbon of the methyl group. Thus, the methyl group of compounds B2, B3, B4, and B6 should have the similar reactivity to that of the compound B1, while the reactivity of methyl group in compound B5 should be lower than that of the compound B1. Thus, compounds B2, B3, B4, and B6 could react with 4-diethylaminobenzaldehyde, but the compound B5 may be difficult to or may not react with it.

(A1)<smiles>Cc1ccncc1</smiles>

(A5)<smiles>Cc1ccncc1C(=O)O</smiles>

(A6)

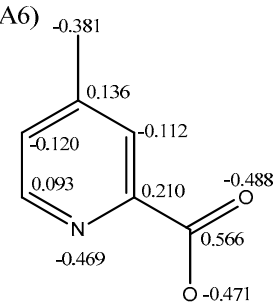

(B4)

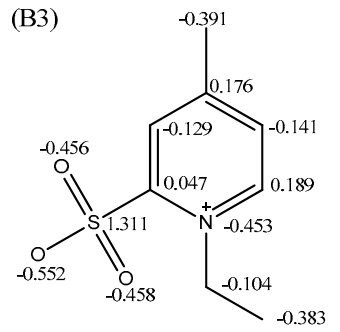<smiles>Cc1ccncc1S(=O)(=O)O</smiles><smiles>Cc1ccnc(S(=O)(=O)O)c1</smiles>

(B1)<smiles>CC[n+]1ccc(C)cc1</smiles>

(B5)<smiles>CC[n+]1ccc(C)c(C(=O)O)c1</smiles>

(A4)<smiles>Cc1cncc(S(=O)(=O)[O-])c1</smiles>

(B2)<smiles></smiles>

(B6)

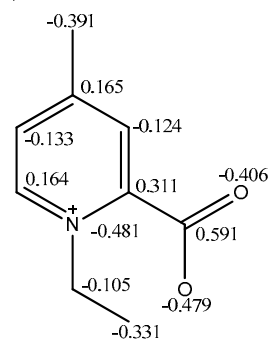

Figure 6. Electronegativity of raw materials and intermediates calculated by Gaussian 09 . (A1) 4-Picoline; (A2) 4-Methylpyridine-3-sulfonic acid; (A3) 4-Methylpyridine-2-sulfonic acid; (A4) 5-Methyl-3-pyridinesulfonic acid; (A5) 4-Methylnicotinic acid; (A6) 4-Methyl-pyridine- 2-carboxyl acid; (B1) 1-ethyl-4-methylpyridin- 1-ium bromide; (B2) 1-ethyl-4-methyl-3-sulfopyridin-1-ium bromide; (B3) 1-ethyl-4-methyl-2-sulfopyridin-1-ium bromide; 1-ethyl-3-methyl-5-sulfopyridin-1-ium bromide; (B5) 3-carboxy-1-ethyl-4-methylpyridin-1-ium bromide; (B6) 2-carboxy-1-ethyl-4-methylpyridin-1-ium bromide.

\subsubsection{Analysis of Enthalpy and Gibbs Free Energy}

The enthalpy of a thermodynamic system is defined in Equation (2) $[62,63]$.

$$
\mathrm{H}=\mathrm{U}+\mathrm{pV}
$$

$\mathrm{H}$ is the enthalpy (SI unit: Joule); $\mathrm{U}$ is the internal energy (SI unit: Joule); $\mathrm{p}$ is pressure (SI unit: Pascal); $\mathrm{V}$ is volume (SI unit: $\mathrm{m} 3$ ). 
The standard enthalpy of formation $\left(\Delta_{\mathrm{f}} \mathrm{H}\right)$ of a compound is the change of enthalpy during the formation of 1 mole of the substance from its constituent elements in their standard states. The standard enthalpy change $\left(\Delta_{\mathrm{r}} \mathrm{H}\right)$ of any reaction can be calculated from the standard enthalpies of formation of reactants and products using Hess's law. It could be illustrated in Equation (3):

$$
\Delta_{\mathrm{r}} \mathrm{H}=\sum \Delta_{\mathrm{f}} \mathrm{H}(\text { products })-\sum \Delta_{\mathrm{f}} \mathrm{H}(\text { reactants })
$$

The Gibbs free energy is defined in Equation (4):

$$
\mathrm{G}=\mathrm{U}+\mathrm{pV}-\mathrm{TS}=\mathrm{H}-\mathrm{TS}
$$

$\mathrm{T}$ is the temperature (SI unit: Kelvin); $\mathrm{S}$ is the entropy (SI unit: Joule per kelvin).

The Gibbs free energy change $(\Delta \mathrm{rG})$ of any reaction can be calculated based on Equation (5):

$$
\Delta_{\mathrm{r}} \mathrm{G}=\sum \Delta_{\mathrm{f}} \mathrm{G} \text { (products) }-\sum \Delta_{\mathrm{f}} \mathrm{G} \text { (reactants) }
$$

According to the first step reaction between derivatives of pyridine and 1-bromoethane (Figure 5a), the reaction could be illustrated as $\mathrm{A}+\mathrm{D} \rightarrow \mathrm{B}$, so the $\Delta \mathrm{rH}$ could be calculated by $\Delta_{\mathrm{r}} \mathrm{H}=\Delta_{\mathrm{f}} \mathrm{H}(\mathrm{B})-\Delta_{\mathrm{f}} \mathrm{H}(\mathrm{A})-\Delta_{\mathrm{f}} \mathrm{H}(\mathrm{D})$, while the $\Delta \mathrm{G}$ could be illustrated as $\Delta_{\mathrm{r}} \mathrm{G}=\Delta_{\mathrm{f}} \mathrm{G}(\mathrm{B})-\Delta_{\mathrm{f}} \mathrm{G}(\mathrm{A})-\Delta_{\mathrm{f}} \mathrm{G}(\mathrm{D})$. The changes of enthalpy and Gibbs free energies in the first step reactions are calculated by Gaussian 09 in ethanol at $80^{\circ} \mathrm{C}$ and shown in Table 6; similarly, the $\Delta \mathrm{rH}$ values of the second reaction in Figure $5 b$ could be illustrated as $\Delta_{r} H=\Delta_{f} H(Z)+\Delta_{f} H(F)-\Delta_{f} H(B)-\Delta_{f} H(E)$, while the $\Delta \mathrm{G}$ values in Table 7 could be calculated by $\Delta_{\mathrm{r}} \mathrm{G}=\Delta_{\mathrm{f}} \mathrm{G}(\mathrm{Z})+\Delta_{\mathrm{f}} \mathrm{G}(\mathrm{F})-\Delta_{\mathrm{f}} \mathrm{G}(\mathrm{B})-\Delta_{\mathrm{f}} \mathrm{G}(\mathrm{E})$. Meanwhile, the bromide ion is not involved in the second step reactions. It seems all designed fluorescent dyes could be produced according to the thermodynamic analysis.

Table 6. The enthalpy and Gibbs free energy values of chemicals in first step and changes of them in ethanol under 353K based on Gaussian 09.

\begin{tabular}{cccccccc}
\hline Item & $\begin{array}{c}\boldsymbol{\Delta}_{\mathbf{f}} \mathbf{H} \\
\text { (Hartree) }\end{array}$ & $\begin{array}{c}\boldsymbol{\Delta}_{\mathbf{f}} \mathbf{G} \\
\text { (Hartree) }\end{array}$ & Item & $\begin{array}{c}\boldsymbol{\Delta}_{\mathbf{f}} \mathbf{H} \\
\text { (Hartree) }\end{array}$ & $\begin{array}{c}\boldsymbol{\Delta}_{\mathbf{f}} \mathbf{G} \\
\text { (Hartree) }\end{array}$ & $\begin{array}{c}\boldsymbol{\Delta}_{\mathbf{r}} \mathbf{H} \\
\text { (Hartree) }\end{array}$ & $\begin{array}{c}\boldsymbol{\Delta} \mathbf{G} \\
\text { (Hartree) }\end{array}$ \\
\hline A1 & -287.48332 & -287.53033 & B1 & -2938.370434 & -2938.438338 & -0.022028 & -0.002863 \\
A2 & -911.256057 & -911.316383 & B2 & -3562.148829 & -3562.223358 & -0.027686 & -0.00183 \\
A3 & -911.264174 & -911.326257 & B3 & -3562.139176 & -3562.218212 & -0.009916 & 0.01319 \\
A4 & -911.258738 & -911.321063 & B4 & -3562.13095 & -3562.212119 & -0.007126 & 0.014089 \\
A5 & -476.036178 & -476.091818 & B5 & -3126.917758 & -3126.99308 & -0.016494 & 0.003883 \\
A6 & -476.039513 & -476.096557 & B6 & -3126.905813 & -3126.980969 & -0.001214 & 0.020733 \\
D & -2650.865086 & -2650.905145 & - & - & - & - & - \\
\hline
\end{tabular}

\begin{tabular}{|c|c|c|c|c|c|c|c|}
\hline Item & $\begin{array}{c}\Delta_{\mathrm{f}} \mathrm{H} \\
\left({ }^{1} \text { Hartree }\right)\end{array}$ & $\begin{array}{c}\Delta_{\mathrm{f}} \mathrm{G} \\
\text { (Hartree) }\end{array}$ & Item & $\begin{array}{c}\Delta_{\mathrm{f}} \mathrm{H} \\
\text { (Hartree) }\end{array}$ & $\begin{array}{c}\Delta_{\mathrm{f}} \mathrm{G} \\
\text { (Hartree) }\end{array}$ & $\begin{array}{c}\Delta \mathrm{H} \\
\text { (Hartree) }\end{array}$ & $\begin{array}{c}\Delta \mathrm{G} \\
\text { (Hartree }\end{array}$ \\
\hline B1 & -366.48955 & -366.545969 & $\mathrm{Z} 1$ & -848.007794 & -848.103322 & 0.015431 & 0.019032 \\
\hline B2 & -990.24633 & -990.315512 & $\mathrm{Z} 2$ & -1471.772855 & -1471.88174 & 0.00715 & 0.010157 \\
\hline B3 & -990.238486 & -990.308045 & $\mathrm{Z3}$ & -1471.762939 & -1471.871835 & 0.009222 & 0.012595 \\
\hline B4 & -990.249985 & -990.320103 & $\mathrm{Z} 4$ & -1471.761824 & -1471.871864 & 0.021836 & 0.024624 \\
\hline B5 & -555.034403 & -555.097776 & $\mathrm{Z} 5$ & -1036.548901 & -1036.654302 & 0.019177 & 0.019859 \\
\hline B6 & -555.02708 & -555.092909 & $\mathrm{Z6}$ & -1036.547848 & -1036.651849 & 0.012907 & 0.017445 \\
\hline $\mathrm{E}$ & -557.924048 & -557.992916 & $\mathrm{~F}$ & -76.390373 & -76.416531 & - & - \\
\hline
\end{tabular}

Table 7. The enthalpy and Gibbs free energy values of chemicals in second step and changes of them in ethanol under 353K based on Gaussian 09.

\footnotetext{
${ }^{1}$ Hartree $=627.509 \mathrm{kcal} \mathrm{mol}^{-1}=27.2116 \mathrm{eV}$.
} 


\subsection{Sample Synthesis Route}

Preparation of Z2: 4-Methylpyridine-3-sulfonicacid (A2) (1.7319 g, $0.01 \mathrm{~mol}$ ) and sodium bicarbonate $\left(\mathrm{NaHCO}_{3}, 0.84 \mathrm{~g}, 0.01 \mathrm{~mol}\right.$ ) were dissolved in a mixture solution (ethanol/water = 2:1) and stirred at room temperature for several minutes. Then, 1-bromoethane $(1.19 \mathrm{~g}, 0.011 \mathrm{~mol})$ was added into the mixture solution, and the mixture was refluxed under $80^{\circ} \mathrm{C}$ for $6 \mathrm{~h}$. Afterward, $1.77 \mathrm{~g}$ of 4-diethylaminobenzaldehyde $(0.01 \mathrm{~mol})$ and several drops of pyridine were added into the mixture; keeping the temperature for $6 \mathrm{~h}$, a crude product was obtained after the solvent was removed by vacuum distillation.

Preparation of Z5: 4-Methylpyridine-3-carboxylic acid (A5) (1.3714 g, $0.01 \mathrm{~mol}$ ) and sodium bicarbonate $\left(\mathrm{NaHCO}_{3}, 0.84 \mathrm{~g}, 0.01 \mathrm{~mol}\right.$ ) were dissolved in a mixture solution (ethanol/water = 2:1) and stirred at room temperature for several minutes. Then, 1-bromoethane $(1.19 \mathrm{~g}, 0.011 \mathrm{~mol})$ was added into the mixture solution, and the mixture was refluxed under $80^{\circ} \mathrm{C}$ for $6 \mathrm{~h}$. Afterward, $1.77 \mathrm{~g}$ of 4-diethylaminobenzaldehyde $(0.01 \mathrm{~mol})$ and several drops of pyridine were added into the mixture; keeping the temperature for $6 \mathrm{~h}$, a crude product was obtained after the solvent was removed by vacuum distillation.

\section{Conclusions}

After computational analyses of design, synthesis, fluorescent properties, photo-stability, as well as estimation of aquatic environmental toxicity of the fluorescent dyes, a dye molecule (Z2) was identified as possessing desired properties and potential environmental friendliness. Both dyes $Z 2$ and $\mathrm{Z} 5$ were prepared and proven to possess ideal fluorescent properties. The Z2 dyed fabrics showed improved light stability, while the Z5 dyed ones shown reduced light stability. The structures of the dye Z2 present features of containing a sulfonic acid group, which could reduce toxicity of the chemicals. Both carboxyl and sulfonic acid groups can improve dyeing properties/affinity to five polymers. The different substituent groups and positions have different influences on the photo-stability of dyes.

Supplementary Materials: Supplementary materials can be found at http://www.mdpi.com/1422-0067/20/23/ 5971/s1.

Author Contributions: Conceptualization, S.T.; software, S.T.; supervision, G.C. and G.S.; writing—original draft, S.T.

Funding: This research was funded by Key R \& D plan of Jiangsu Province, BE2019001-3.

Acknowledgments: Songsong Tang is grateful for a scholarship from Soochow University for financially sponsoring his research activities at University of California, Davis.

Conflicts of Interest: The authors declare no conflict of interest.

\section{References}

1. Das, P.P.; Roy, A.; Agarkar, S.; Devi, P.S. Hydrothermally synthesized fluorescent $\mathrm{Zn}_{2} \mathrm{SnO}_{4}$ nanoparticles for dye sensitized solar cells. Dye. Pigment. 2018, 154, 303-313. [CrossRef]

2. Ooyama, Y.; Nagano, T.; Inoue, S.; Imae, I.; Komaguchi, K.; Ohshita, J.; Harima, Y. Dye-Sensitized Solar Cells Based on Donor- $\pi$-Acceptor Fluorescent Dyes with a Pyridine Ring as an Electron-Withdrawing-Injecting Anchoring Group. Chem. Eur. J. 2011, 17, 14837-14843. [CrossRef] [PubMed]

3. Cao, Y.; Wang, X.; Shi, X.; Clee, S.M.; McGeer, P.L.; Wolf, M.O.; Orvig, C. Biological Imaging with Medium-Sensitive Bichromatic Flexible Fluorescent Dyes. Angew. Chem. Int. Ed. 2017, 56, 15603-15606. [CrossRef] [PubMed]

4. Li, Q.; Liu, W.; Wu, J.; Zhou, B.; Niu, G.; Zhang, H.; Ge, J.; Wang, P. Deep-red to near-infrared fluorescent dyes: Synthesis, photophysical properties, and application in cell imaging. Spectrochim. Acta A 2016, 164, 8-14. [CrossRef] [PubMed]

5. Tang, Y.; Lee, D.; Wang, J.; Li, G.; Yu, J.; Lin, W.; Yoon, J. Development of fluorescent probes based on protection-deprotection of the key functional groups for biological imaging. Chem. Soc. Rev. 2015, 44, 5003-5015. [CrossRef] 
6. Cotruvo, J.A., Jr.; Aron, A.T.; Ramos-Torres, K.M.; Chang, C.J. Synthetic fluorescent probes for studying copper in biological systems. Chem. Soc. Rev. 2015, 44, 4400-4414. [CrossRef] [PubMed]

7. Kolmakov, K.; Hebisch, E.; Wolfram, T.; Lars, A.; Nordwig, L.A.; Wurm, C.A.; Ta, H.; Westphal, V.; Belov, V.S.W. Far-Red Emitting Fluorescent Dyes for Optical Nanoscopy: Fluorinated Silicon-Rhodamines (SiRF Dyes) and Phosphorylated Oxazines. Chem. Eur. J. 2015, 21, 13344-13356. [CrossRef]

8. Sahl, S.J.; Hell, S.W.; Jakobs, S. Fluorescence nanoscopy in cell biology. Nat. Rev. Mol. Cell. Biol. 2017, 18, 685-701. [CrossRef]

9. Ahlström, L.H.; Eskilsson, C.S.; Björklund, E. Determination of banned azo dyes in consumer goods. TrAC Trends Anal. Chem. 2005, 24, 49-56. [CrossRef]

10. Brüschweiler, B.J.; Küng, S.; Bürgi, D.; Muralt, L.; Erich Nyfeler, E. Identification of non-regulated aromatic amines of toxicological concern which can be cleaved from azo dyes used in clothing textiles. Regul. Toxicol. Pharmacol. 2014, 69, 263-272. [CrossRef]

11. Fadadu, K.B.; Soni, S.S. Spectral sensitization of $\mathrm{TiO}_{2}$ by new hemicyanine dyes in dye solar cell yielding enhanced photovoltage: Probing chain length effect on performance. Electrochim. Acta 2013, 88, 270-277. [CrossRef]

12. Jędrzejewska, B.; Kabatc, J.; Pączkowski, J. Dichromophoric hemicyanine dyes. Synthesis and spectroscopic investigation. Dye. Pigment. 2007, 74, 262-268. [CrossRef]

13. Zhang, C.; Liu, Z.; Chen, Y.; Ma, J.; Chen, H.S.; Zhang, M.L. Density Functional Theory Study on Organic Dye Sensitizers Containing Bis-dimethylfluorenyl Amino Benzofuran. Chin. J. Chem. Phys. 2009, 22, 489-496. [CrossRef]

14. Wang, Z.S.; Li, F.Y.; Huang, C.H. Photocurrent enhancement of hemicyanine dyes containing $\mathrm{RSO}_{3}$-group through treating $\mathrm{TiO}_{2}$ films with hydrochloric acid. J. Phys. Chem. B 2001, 105, 9210-9217. [CrossRef]

15. Das, P.J.; Das, J.; Das, D. An Efficient Conversion of Alcohols to Alkyl Bromides Using Pyridinium Based Ionic Liquids: A Green Alternative to Appel Reaction. Asian J. Chem. 2018, 30, 651-654. [CrossRef]

16. Jin, F.; Cai, Z.B.; Huang, J.Q.; Sheng, L.L.; Yu, P.T. Investigation of two-photon absorption properties in new A-D-A compounds emitting blue and yellow fluorescence. J. Mol. Struct. 2015, 1093, 33-38. [CrossRef]

17. Krieg, R.; Eitner, A.; Günther, W.; Halbhuber, K.J. Optimization of heterocyclic 4-hydroxystyryl derivatives for histological localization of endogenous and immunobound peroxidase activity. Biotech. Histochem. 2007, 82, 235-262. [CrossRef]

18. Ikeda, T.; Tadaki, Y.; Funajima, R.; Tatewaki, Y.; Okad, S. Aminostilbazolium Derivatives Substituted by Hydroxyethyl Groups for Second-Order Nonlinear Optics. Mol. Cryst. Liq. Cryst. 2011, 539, $142-147$. [CrossRef]

19. Wei, B.X.; Zhao, L.; Wang, T.J.; Gao, H.; Wu, H.X.; Jin, Y. Photo-stability of TiO2 particles coated with several transition metal oxides and its measurement by rhodamine-B degradation. Adv. Powder Technol. 2013, 24, 708-713. [CrossRef]

20. Yang, S.; Tian, H.; Xiao, H.; Shang, H.; Gong, X.D.; Yao, S.; Chen, K. Photodegradation of cyanine and merocyanine dyes. Dye. Pigment. 2001, 49, 93-101. [CrossRef]

21. Chang, X.P.; Gao, Y.J.; Fang, W.H.; Cui, G.; Thiel, W. Quantum Mechanics/Molecular Mechanics Study on the Photoreactions of Dark-and Light-Adapted States of a Blue-Light YtvA LOV Photoreceptor. Angew. Chem. 2017, 129, 9469-9473. [CrossRef]

22. Zhan, Y.Z.; Zhao, X.; Wang, W. Theoretical study of the interaction energy of benzodifuranone dye molecule rings. Color. Technol. 2017, 133, 50-56. [CrossRef]

23. Zhan, Y.; Zhao, X.; Wang, W. Synthesis of phthalimide disperse dyes and study on the interaction energy. Dye. Pigment. 2017, 146, 240-250. [CrossRef]

24. Sokołowska, J.; Czajkowski, W.; Podsiadły, R. The photostability of some fluorescent disperse dyes derivatives of coumarin. Dye. Pigment. 2001, 49, 187-191. [CrossRef]

25. Patel, D.R.; Bilimoriya, J.T.; Patel, B.M.; Paresh, S.; Patel, S.H.; Mehta, K.M.; Patel, S.A.; Patel, K.C.; Patel, B.S.; Sahoo, S.K. Monoazo Styryl Quinazolinone Reactive Dyes: Their Synthesis, Application and Density Function Theory (DFT) Calculation. Proc. Nat. Acad. Sci. India Sect. A 2017, 87, 339-348. [CrossRef]

26. Cash, G.G. Prediction of chemical toxicity to aquatic organisms: ECOSAR vs. Microtox ${ }^{\circledR}$ Assay. Environ. Toxicol. Water Qual. 1998, 13, 211-216. [CrossRef]

27. Tang, S.; Zhao, C.; Chen, G.; Sun, G. A study on computerized selection of fluorescent dyes for environmentally friendly textile applications. Dye. Pigment. 2019, 165, 256-263. [CrossRef] 
28. Karst, D.; Yang, Y. Using the solubility parameter to explain disperse dye sorption on polylactide. J. Appl. Polym. Sci. 2005, 96, 416-422. [CrossRef]

29. Tamizifar, M.; Sun, G. Control of surface radical graft polymerization on polyester fibers by using Hansen solubility parameters as a measurement of the affinity of chemicals to materials. RSC Adv. 2017, 7, 13299-13303. [CrossRef]

30. Knox, B.H.; Weigmann, H.D.; Scott, M.G. Interactions of nonaqueous solvents with textile fibers: Part V: Application of the solubility parameter concept to polyester fiber-solvent interactions. Text. Res. J. 1975, 45, 203-217. [CrossRef]

31. Montgomery, J.A., Jr.; Frisch, M.J.; Ochterski, J.W.; Petersson, G. A complete basis set model chemistry. VI. Use of density functional geometries and frequencies. J. Chem. Phys. 1999, 110, 2822-2827. [CrossRef]

32. Baboul, A.G.; Curtiss, L.A.; Redfern, P.C.; Redfern, P.C.; Raghavachari, K. Gaussian-3 theory using density functional geometries and zero-point energies. J. Chem. Phys. 1999, 110, 7650-7657. [CrossRef]

33. Zhao, Y.; Truhlar, D.G. The M06 suite of density functionals for main group thermochemistry, thermochemical kinetics, noncovalent interactions, excited states, and transition elements: Two new functionals and systematic testing of four M06-class functionals and 12 other functionals. Theor. Chem. Acc. 2008, 120, 215-241.

34. Curtiss, L.A.; Redfern, P.C.; Raghavachari, K.; Raghavachari, K.; Pople, J.A. Gaussian-3X (G3X) theory: Use of improved geometries, zero-point energies, and Hartree-Fock basis sets. J. Chem. Phys. 2001, 114, 108-117. [CrossRef]

35. Cai, Z.L.; Crossley, M.J.; Reimers, J.R.; Kobayashi, R.; Amos, R.D. Density functional theory for charge transfer: The nature of the N-bands of porphyrins and chlorophylls revealed through CAM-B3LYP, CASPT2, and SAC-CI calculations. J. Phys. Chem. B 2006, 110, 15624-15632. [CrossRef]

36. Civalleri, B.; Zicovich-Wilson, C.M.; Valenzano, L.; Ugliengo, P. B3LYP augmented with an empirical dispersion term (B3LYP-D*) as applied to molecular crystals. Cryst Eng Comm 2008, 10, 405-410. [CrossRef]

37. Jacquemin, D.; Preat, J.; Perpète, E.A. A TD-DFT study of the absorption spectra of fast dye salts. Chem. Phys. Lett. 2005, 410, 254-259. [CrossRef]

38. Guillaumont, D.; Nakamura, S. Calculation of the absorption wavelength of dyes using time-dependent density-functional theory (TD-DFT). Dye. Pigment. 2000, 46, 85-92. [CrossRef]

39. Xie, L.; Chen, Y.; Wu, W.; Guo, H.; Zhao, J.; Yu, X. Fluorescent coumarin derivatives with large stokes shift, dual emission and solid state luminescent properties: An experimental and theoretical study. Dye. Pigment. 2012, 92, 1361-1369. [CrossRef]

40. Shao, J.; Sun, H.; Guo, H.; Ji, S.; Zhao, J.; Wu, W.; James, T.D. A highly selective red-emitting FRET fluorescent molecular probe derived from BODIPY for the detection of cysteine and homocysteine: An experimental and theoretical study. Chem. Sci. 2012, 3, 1049-1061. [CrossRef]

41. Huynh, H.V.; He, X.; Baumgartner, T. Halochromic generation of white light emission using a single dithienophosphole luminophore. Chem. Commun. 2013, 49, 4899-4901. [CrossRef]

42. Frisch, M.J.; Trucks, G.W.; Schlegel, H.B.; Scuseria, G.E.; Robb, M.A.; Cheeseman, J.R.; Petersson, G.A. Gaussian 09, revision A. 1. Gaussian Inc. Wallingford CT 2009, 27, 34.

43. Netzeva, T.I.; Pavan, M.; Worth, A.P. Review of (quantitative) structure-activity relationships for acute aquatic toxicity. QSAR Comb. Sci. 2008, 27,77-90. [CrossRef]

44. Cronin, M.T.D. Predicting Chemical Toxicity and Fate. In The Use by Governmental Regulatory Agencies of quantitative Structure-Activity Relationships and Expert Systems to Predict Toxicity; CRC Press: Boca Raton, FL, USA, 2004; pp. 414-425.

45. Nickell, J.R.; Culver, J.P.; Janganati, V.; Zheng, G.; Dwoskin, L.P.; Crooks, P.A. 1, 4-Diphenalkylpiperidines: A new scaffold for the design of potent inhibitors of the vesicular monoamine transporter-2. Bioorganic Med. Chem. Lett. 2016, 26, 2997-3000. [CrossRef]

46. Hauser, S.A.; Korinth, V.; Herdtweck, E.; Cokoja, M.; Herrmann, W.A.; Kühn, F.E. Chromophoric Lewis Base Adducts of Methyltrioxorhenium: Synthesis, Catalysis and Photochemistry. Eur. J. Inorg. Chem. 2010, 26, 4083-4090. [CrossRef]

47. Lacroix, P.G.; Munoz, M.C.; Gaspar, A.B.; Gaspar, A.B.; Real, J.A.; Bonhommeau, S.; Rodriguez, V.; Nakatani, K. Synthesis, crystal structures, and solid state quadratic nonlinear optical properties of a series of stilbazolium cations combined with gold cyanide counter-ion. J. Mater. Chem. 2011, 21, 15940-15949. [CrossRef] 
48. Agustí, G.; Gaspar, A.B.; Muñoz, M.C.; Lacroix, P.G.; Real, J.A. Spin Crossover and Paramagnetic Behaviour in Two-Dimensional Iron (ii) Coordination Polymers with Stilbazole Push-Pull Ligands. Aust. J. Chem. 2009, 62, 1155-1165. [CrossRef]

49. Cicchi, S.; Fabbrizzi, P.; Ghini, G.; Brandi, A.; Foggi, P.; Marcelli, A.; Botta, C. Pyrene-Excimers-Based Antenna Systems. Chem. Eur. J. 2009, 15, 754-764. [CrossRef]

50. Li, D.; Sun, X.; Shao, N.; Wu, J.; Tian, Y. Self-Assembly of Organic Chromosphere Cations with Inorganic Lanthanide (III) Complex Counterions. Zeitschrift Für Anorganische Und Allgemeine Chemie 2014, 640, 2283-2286. [CrossRef]

51. Hao, F.; Zhang, X.; Tian, Y.; Zhou, H.; Li, L.; Wu, J.; Zhou, G. Design, crystal structures and enhanced frequency-upconverted lasing efficiencies of a new series of dyes from hybrid of inorganic polymers and organic chromophores. J. Mater. Chem. 2009, 19, 9163-9169. [CrossRef]

52. Guggenheim, E.A. Thermodynamics-an advanced treatment for chemists and physicists. In Thermodynamics - An Advanced Treatment for Chemists and Physicists, 7th ed.; Amsterdam, North-Holland: New York, NY, USA, 1985; p. 414.

53. Zumdahl, S.S. Thermochemistry. In Chemistry; Cengage Learning: Boston, MA, USA, 2008; p. 243.

54. Strickler, S.J.; Berg, R.A. Relationship between absorption intensity and fluorescence lifetime of molecules. J. Chem. Phys. 1962, 37, 814-822. [CrossRef]

55. Mohammad, M.A.; Alhalaweh, A.; Velaga, S.P. Hansen solubility parameter as a tool to predict cocrystal formation. Int. J. Pharm. 2011, 407, 63-71. [CrossRef]

56. Hansen, C.M. Aspects of solubility, surfaces and diffusion in polymers. Prog. Org. Coat. 2004, 51, 55-66. [CrossRef]

57. Qi, H.; Zhao, C.; Qing, F.L.; Yan, K.; Sun, G. Antiwrinkle finishing of cotton fabrics with 5-(Carbonyloxy succinic)-benzene-1, 2, 4-tricarboxylic acid: Comparison with other acids. Ind. Eng. Chem. Res. 2016, 55, 11850-11856. [CrossRef]

58. Launay, H.; Hansen, C.M.; Almdal, K. Hansen solubility parameters for a carbon fiber/epoxy composite. Carbon 2007, 45, 2859-2865. [CrossRef]

59. Ji, B.; Zhao, C.; Yan, K.; Sun, G. Effects of acid diffusibility and affinity to cellulose on strength loss of polycarboxylic acid crosslinked fabrics. Carbohydr. Polym. 2016, 144, 282-288. [CrossRef]

60. Qin, C.; Qin, Z. Research on the fluorescent whiteners for textiles. Text. Aux. 2005, 9, 1-3.

61. Christie, R.M. Review of Progress in Coloration and Related Topics. Fluoresc. Dye. 1993, 23, 1-18.

62. Bi, L.; Zhang, W.; QIN, C. Dyeing behaviors of three phthalocyanine dyes on acrylic fabric. China Dye. Finish. 2014, 8, 1-4.

63. Tang, S.; Qin, C.; Chen, G.; Bao, Z.M.; Hou, X.N. Synthesis and dyeing properties of three hemicyanine-based fluorescent polymeric dyes. AATCC J. Res. 2018, 5, 19-25. [CrossRef] 